\title{
Autoimmune rheumatic diseases and Klinefelter syndrome Autoimunitné reumatické choroby a Klinefelterov syndróm
}

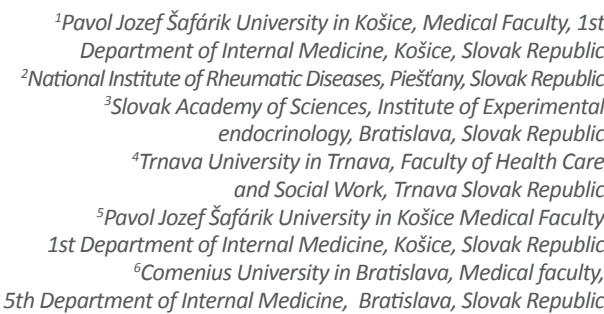

${ }^{1}$ Pavol Jozef Šafárik University in Košice, Medical Faculty, 1st Department of Internal Medicine, Košice, Slovak Republic lovak Academy of Sciences, Institute of Experimenta endocrinology Bratislava, Slovak Republic 5th Department of Internal Medicine, Bratislava, Slovak Republic

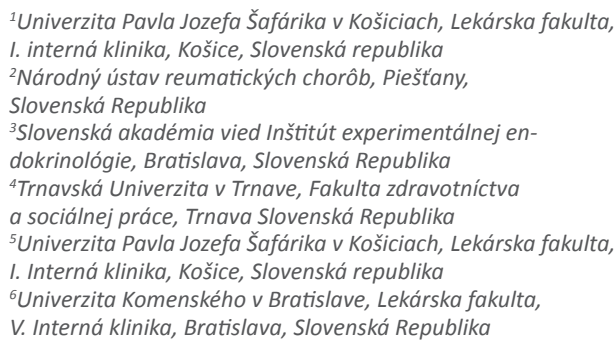

Received 22 June, 2016, accepted 19 July, 2016

Abstract The article summarizes data on the association of Klinefelter syndrome (KS) with autoimmune rheumatic diseases, that is rheumatoid arthritis (RA), systemic lupus erythematosus (SLE), polymyositis/dermatomyositis, systemic sclerosis (SSc), mixed connective tissue diseases (MCTD), Sjogren's syndrome and antiphospholipid syndrome (APS). Recently, a higher risk for RA, SLE and Sjogren's syndrome in patients with KS has been clearly demonstrated. However, the association of other autoimmune rheumatic disorders such as dermatomyositis/polymyositis, SSC, MCTD and APS is reported only casually. Based on the hormonal changes in KS, there are suggestions that low androgen and higher estrogen levels might be a predisposing factor for the development of autoimmune diseases, but evidence for the association is poor. Epidemiologic studies on larger cohorts of patients are required.

Slovak Práca sumarizuje dostupné údaje o asociácii Klinefelterovho syndrómu (KS) s autoimunitnými reumatickými chorobami, t.j. reabstract umatoidnou artritídou (RA), systémovým lupus erythematosus (SLE), polymyozitídou/dermatomyozitídou, systémovou sklerózou (SSc), zmiešaným ochorením spojiva (MCTD), Sjogrenovým syndrómom a antifosfolipidovým syndrómom (APS). Nedávno bolo preukázané vyššie riziko RA, SLE a Sjogrenovho syndrómu u pacientov s KS. Avšak asociácia s inými autoimunitnými chorobami, ako sú dermatomyozitída/polymyozitída, SSc, MCTD a APS je zatial' publikovaná iba kazuisticky. Na základe hormonálnych zmien, ktoré sú typické pre KS sa predpokladá, že nízka hladina androgénov a vyššie hladiny estrogénov môžu byt̉ predispozičnými faktormi v etiopatogenéze autoimunitných chorôb, ale dôkazy pre túto asociáciu v literatúre sú zatial' chudobné. Vyžadujú si epidemiologické štúdie na väčších súboroch pacientov.

Keywords Klinefelter syndrome - rheumatoid arthritis - polymyositis/dermatomyositis - systemic lupus erythematosus - systemic sclerosis - antiphospholipid syndrome

Klúčové Klinefelterov syndróm - reumatoidná artritída - polymyozitída/dermatomyozitída - systémový lupus erythematosus - systémová skleróza slová: antifosfolipidový syndróm

\section{INTRODUCTION}

Klinefelter syndrome (KS) is a genetic chromosomal abnormality associated with the presence of one additional $\mathrm{X}$ chromosome due to the abnormal division characterized by a typical karyotype of $47 \mathrm{XXY}$ (classic form) or $46, \mathrm{XY} / 47, \mathrm{XXX}$ (mosaic form). Studies with Southern blotting indicate that the additional $\mathrm{X}$ chromosome is equally likely to be of maternal origin. The disease is usually manifested by typical somatic features, microorchidism, gynecomastia and infertility. Typical somatic changes include acromicria, clinodactyly or other abnormalities; spinal osteoporosis is usually manifested not only in adults but also in younger KS patients. 
In large population studies, the incidence of KS has been estimated to be 1:1000 live born male babies. It is assumed that more than $50 \%$ of males are not recognized and approximately $90 \%$ of those identified are diagnosed postpubertal (Aksglaede L et al., 2013).

It is well known that the autoimmune rheumatic diseases are more common in females because of higher levels of estrogens in comparison with androgens. However, because of the additional $\mathrm{X}$ chromosome in patients with $\mathrm{KS}$, resulting in hypogonadism with lower androgen and higher estrogen levels, there is an arising hypothesis on the increased prevalence and also, a higher risk of autoimmune disorders in males with this syndrome. The data from the literature are poor and epidemiological studies are missing.

Therefore, the aim of this article is to summarize all data on the relationship between $\mathrm{KS}$ and various autoimmune rheumatic diseases.

\section{KLINEFELTER SYNDROME AND RHEUMATOID ARTHRITIS (RA)}

Based on hormonal status and several case reports that have been published until recently, there are suggestions that people with KS may be at an increased risk of some autoimmune diseases, but the evidence is still poorly documented.

In a formerly published article of Bošmanský and Kopecký (Bosmanský et Kopecky, 1979), the authors have described a case of rheumatoid arthritis (RA) and seropositivity of rheumatoid factor in a patient with KS. RA had a clearly benign course with slow progression, and minimal exudative manifestations related to RA activity. The patient died after suffering from myocardial infarction. In their report, authors pointed to the relatively rare coincidence of KS and RA.

Later on, various case reports of patients with KS and rheumatoid arthritis have been published, suggesting that the association of both disorders is not extremely rare (Lamotte et al., 1965, Mac Swen et al., 1965, Tsung et Heckman, 1974). Unfortunately, the epidemiological study on a large group of KS patients was missing. Recently, in the English national record linkage study, approximately 30 autoimmune diseases were studied in a large group of people with KS. The risk for rheumatoid arthritis was significantly higher in KS (RR 3.3, 95\% Cl 2.0-5.2) and the disease was identified among seven most common autoimmune disorders associated with KS (Seminoq et al., 2015).

Pathogenesis of association of autoimmune disorders including RA and KS is still completely unrecognized. Low testosterone levels or increased estradiol to testosterone ratio have been considered as a contributing factor in the development of rheumatic disease. In some studies, the estradiol is positively correlated with the degree of inflammation in males affected by RA (Cutolo et al., 2004, Castagnetta et al., 2003). In addition, the local action of gonadal steroids, including their conversion to active metabolites or receptor sensitivity in tissues affected with inflammation, may also play an important role in the pathogenesis of RA (Rovensky et al., 2005). Furthermore, genetic abnormalities in androgen receptor coding genes, such as polyglutamine repeat length, were found to contribute to the phenotypic variability in KS suggesting alterations in androgen action that may play a role in the development of autoimmunity in KS as well (Zinn et al., 2005). In the report of Kobayashi and colleagues, the course of RA was benign, similar to previous reports (Kobyashi et al., 1994). On the other hand, Al-Arfaj described a patient with KS who had seropositive erosive rheumatoid arthritis, suggesting that in association with KS, rheumatoid arthritis may be more erosive (Al-Arfaj, 2010). Whether hormonal changes are responsible for benign or aggressive course of the rheumatoid arthritis is unknown and requires further studies.

\section{KS AND SYSTEMIC LUPUS ERYTHEMATOSUS (SLE)}

Similar to other autoimmune diseases, SLE predominantly affects women. Previously, several cases of SLE in people with KS have been reported and the association of SLE with KS has been reported only casually (Oritz-Neu et Le Roy, 1969, Wittori et Desaegher, 1977). In 1991, the authors described the case of a 22-year-old male in whom SLE was presented by Raynaud's phenomenon with necrosis of the fingers, dyspnea, and chest pain due to pleuritis. Among the laboratory parameters, the presence of antinuclear antibodies (ANA) was also detected. Ten years later, the patient was admitted again because of a skin rash, sensitivity to sun, and ulcers in the oral cavity. Moreover, Raynaud's phenomenon was present with fingertip necrosis, and lymphadenopathy was found. Laboratory parameters showed leucopenia, high inflammatory markers, positivity of ANA and anti-ds DNA antibodies, anti-cardiolipin antibodies and lupus anticoagulants. The hormonal evaluation demonstrated decreased serum testosterone and elevated serum estrogen levels. KS was confirmed by genetic testing (Folomeev et al., 1991). Subsequently, Stern and colleagues studied the urinary estrogen levels in KS and SLE. One patient had elevated levels of all three urinary estrogens (estrone, estradiol, and estriol) with markedly increased estriol values (Stern et al., 1977). Moreover, some authors pointed to the fact that estradiol levels are frequently elevated in KS, reaching values as measured in women with the normal menstrual cycle, whereas androgen levels are similar to those found in prepubertal age males. Therefore, it can be hypothesized that estrogens seem to play a role in the modulation of the immune system, and subsequently, in the pathogenesis of SLE itself (Lahita 1986). Other studies also confirmed that serum androgen levels, including testosterone, androstenedione, dehydroepiandrosterone, and dehydroepiandrosterone sulfate are reduced in SLE (Michalski et al., 1978). According to others, the metabolism of 
sexual steroids in males with KS was similar to that observed in women suffering from SLE (Lahita et Bradlow, 1987, French et Hughes, 1983). It is still unclear whether hyperestrogenism or lack of testosterone is responsible for the development of autoimmunity in these individuals. Androgens seem to be natural immunosuppressors, and their deficiency was observed in SLE and in RA males.

An interesting case report of patient with SLE and KS was published by Gilliland and Stashower, who described a case of a 12-year-old boy suffering from epileptic episodes from the age of 4 years. Initially, he developed skin manifestations on face and shoulders, as well as in the auricular region. Biopsy suggested discoid lupus erythematosus. Weakness and arthritis of small joints developed after several months. ANA and anti-dsDNA antibodies were positive. The disease was controlled with antimalarial agents and prednisone. Upon a follow-up examination at the age of 6 years, the patient was found to have small testes. Genetic testing confirmed the presence of KS with typical hormonal changes (Gilliland WR et Stashower, 2000). Furthermore, many authors published one or more cases with association of both KS and SLE, and its various manifestations (Jimenez-Balderas et al., 2001, Dubois et Kaplan, 1976, Goto et al., 2011).

Besides case reports, there are some studies on smaller groups of patients with the aim to estimate the prevalence of KS in males with SLE with various findings. In one study, none of the 22 patients with SLE was identified to have KS (Dubois et Kaplan, 1976). However, in another study among 286 men with SLE, seven of them were diagnosed with KS (Dillon et al., 2011). On the other hand, in the English national record linkage studies, SLE was among the seven most common autoimmune diseases detected in patients with KS with RR 18.1, 95\% Cl 2.2-65.6 (Seminoq et al., 2015).

Recently, a large genotyping study in SLE patients revealed that of the 213 SLE men, five had KS (47, XXY) genotype. The risk of SLE in men with 47, XXY genotype has been calculated to be approximately 14-times higher than in men with 46, XY genotype, consistent with the notion that SLE susceptibility is partially explained by an $X$ chromosome gene-dose effect (Scofield et al., 2008). Such effect could be mediated by abnormal inactivation of genes on the $\mathrm{X}$ chromosome, as has been demonstrated for CD40L, or by genetic polymorphism as has been demonstrated for Xq28. On the other hand, a gene dose effect could also be mediated by a gene without an SLE-associated polymorphism in that a gene that avoids $X$ inactivation will have a higher level of expression in subjects with two $X$ chromosomes (Sawalha et al., 2009) .

\section{KS AND POLYMYOSITIS/DERMATOMYSITIS}

The association between KS and polymyositis/ dermatomyositis is unclear and reported only by some cases. Formerly, Rovensky and colleagues demonstrated a case of a patient with KS and antisynthetase syndrome \{Raynaud's phenomenon, acrosclerosis, mechanic's hands, mild weakness of proximal muscles of the hands, presence of interstitial pulmonary fibrosis, tendency to recurrent infections, and secondary Sjogren's syndrome) (Rovensky et al., 2003). The presence of anti-Jo-1 antibody together with anti-Ro and anti-La antibodies was detected. Two cases of a similar association have been published by others (Nielsen et al., 1999, Murakami et al., 1988), however, there is no evidence on higher risk of the disease in patients with KS and oppositely, there is lack of evidence on higher prevalence of KS among patients with polymyositis/dermatomyositis.

\section{KS AND SYSTEMIC SCLEROSIS (SSC)}

Nowlin and colleagues described the association of KS with systemic sclerosis for the first time in 1985 (SSc) (Nowlin et al., 1985). In one of two patients described in this paper, hypogonadism has been presented prior to the development of SSc. Authors discussed the role of testicular failure as a disease-modifying factor in SSc. In another patient, Raynaud's phenomenon was associated with lack of androgens. Testicular fibrosis along with vasculopathy is believed to contribute to gonadal failure in SSc. In another report, a case of association of both SSC and KS with the clinical picture of sclerodactyly and bilateral basilar pulmonary fibrosis, synovitis of the MCP joints was demonstrated. In this report, the authors have hypothesized the potential effects of $\mathrm{KS}$ on the development of autoimmune syndromes similar to other autoimmune diseases (see above) (O’Donghue 1982). The association of KS with SSc has been published casually by others; however, the risk of the disease in men with KS is uncertain (De Keyser et al., 1989).

\section{KS AND MIXED CONNECTIVE TISSUE DISEASE (MCTD) AND SJOGREN'S SYNDROME}

There are only some reports on the occurrence of MCTD in patients with KS. Takeuchi and colleagues published a report of a patient with $\mathrm{KS}$ suffering from mixed connective tissue disease (MCTD), diabetes mellitus, and some other endocrine disturbances, such as hypothyroidism and primary hypocorticism (Takeuchi et al., 1999). Subsequently, Kasten and colleagues described a 43-year-old male with eunuchoid body proportions and a history of deep venous thromboses in the right leg with an occurrence of recurrent ulcers in the right perimalleolar region for 6 years. Karyotyping revealed a $47 \mathrm{XXY}$ genotype, clinical and laboratory evaluations confirmed MCTD suggesting that patients with KS are prone to develop connective tissue diseases (Kasten et al., 1995). Similar case report has been published by Japanese authors describing a patient with KS who developed MCTD and Sjögren's syndrome. A relative increase of peripheral CD8+ $T$ cells carrying either HLA-DR or CD57 was found 
Table 1. Summary of currently available data on a risk for rheumatic autoimmune diseases in patients with KS

\begin{tabular}{|c|c|}
\hline Non-organ specific autoimmune disease & Evidence for a risk \\
\hline Rheumatoid arthritis & Higher risk (RR 3.3) \\
\hline Systemic lupus erythematodes & Higher risk (RR 18.1) \\
\hline Sjogren's syndrome & Higher risk (RR 19.3) \\
\hline Systemic sclerosis & No evidence, only case reports \\
\hline Antiphospholipid syndrome reports \\
\hline Polymyositis/dermatomyositis & No evidence, only case reports \\
\hline
\end{tabular}

$R R$ - relative risk for the disease according to Seminoq et al., 2015

in the patient (Ishihara et al., 1997). Although there are no epidemiological studies demonstrating higher prevalence of Sjogren's syndrome until recently, the relative risk for Sjogren's syndrome in the English national record linkage study in people with KS was significant (RR 19.3, 95\% Cl 4.0 - 5.7) (Seminoq et al., 2015). The potential role of additional $X$ chromosome in the development of Sjogren's syndrome is supported by a recent case report from Japan describing a 16-year-old patient with trisomy X (47 XXX) who developed MCTD and Sjogren's syndrome. The patient was positive for antinuclear antibody, anti-nRNP antibody and rheumatoid factor (Fujimoto et al., 2015).

\section{KS AND ANTIPHOSPHOLIPID SYNDROME (APS)}

The association of the antiphospholipid syndrome (APS) with KS was first described in 1993. Subsequently, two cases of SLE with a secondary APS in KS were reported by Folomeev and others. Some authors pointed to the fact that the immune mechanism including the beta2-GP1 cofactor may contribute to the reasons underlying the vascular alterations in $\mathrm{KS}$ (Miyagawa et al., 1995, Amstrong et al., 1985).

\section{CONCLUSION}

Because of relatively low prevalence of non-organ specific autoimmune diseases in males and also low prevalence of Klinefeter syndrome in population, the data on association of KS with these disorders is still poor. Recently, a higher risk for RA, SLE and Sjogren's syndrome in patients with KS has been clearly demonstrated by English national record linkage studies. The association of other autoimmune rheumatic disorders such as dermatomyositis/polymyostitis, systemic sclerosis, MCTD and antiphospholipid syndrome is still reported only casually, and the evidence on higher risk of these diseases is missing (Table 1). However, with respect to the hormonal changes in KS, there are suggestions that this syndrome resulting in low testosterone and higher estrogen levels might be a predisposing factor for the development of autoimmune diseases. Unfortunately, there are no prospective studies on the prevalence of non-organ-specific autoimmunity, as well as autoimmune rheumatic disorders on large cohort of patients with KS. However, it appears that patients with KS should be monitored from the aspect of the development of various autoimmune diseases.

\section{References}

[1] Aksglaede L, Link K, Giwercman A, Jørgensen N, Skakkebaek NE, Juul A. 47 XXZ Klinefelter syndrome: clinical characteristics and age specific recommendations for medical management. Am J Med Genet C Semin Med Genet. 2013 Feb 15;163C(1):55-63

[2] Bosmansky K., Kopecký S. Progresívna polyartritída a Klinefelterov syndróm [Progressive polyarthritis and Klinefelter's syndrome). Fysiatr. Revmatol. Věstn. 57, 1979: 160-163.

[3] Lamotte MC, Labrousse, M. Perrault A, et al. Polyarthrite rheumatoide sévère, diabète insulino - résistant, syndrome de Klinefelter. Sem. Hop. Paris 41, 525-528 (1965)

[4] Mac Sween, R.N.M. Reticulum cell sarcoma and rheumatoid arthritis in patient with XY /XXY/XXXY Klinefelter's syndrome and normal intelligence. Lancet 1965,1: 460-464.
[5] Tsung SH, Heckman MG. Klinefelter's syndrome, immunological disorders and malignant neoplasm. Arch. Pathol. 1974, 98: 351354.

[6] Kobayashi S, Yamamoto S, Tanaka M. et al. Klinefelter's syndrome and rheumatoid arthritis report of a case and review of the literature, Clin. Rheumatol. 1994, 13: 500-503.

[7] Seminoq OO, Seminoq AB, Yeates D, Goldcare MJ. Associations between KS and autoimmune diseases: English national record linkage studies. Autoimmunity, 2015, 48: 125-8

[8] Cutolo M, Sulli A, Capellino $S$,et al. Sex hormones influence on the immune system: basic and clinical aspects in autoimmunity. Lupus, 2004, 13: 635-638. 
[9] Castagnetta, LA, Carruba G, Granata OM, et al. Increased estrogen formation and estrogen to androgen ratio in the synovial fluid of patients with rheumatoid arthritis. Rheumatol. 2003, 30:

[10] Rovenský J, Kvetnansky R, Radikova Z et al. Hormone concentrations in synovial fluid of patients with rheumatoid arthritis. Clin. Exp. Rheumatol. 2005, 23:292296.

[11] Zinn AR., Ramos P, Elder FF, et al. Androgen receptor CAGn repeat length influences phenotype of 47, XXY (Klinefelter) syndrome. Clin. Endocrinol. Metab. 2005, 90: 5041-5046,

[12] Al-Arfaj HF. Klinefelter's syndrome and rheumatoid arthritis: report of a case and review of the literature. Int J Rheum Dis, 2010, 13: 86-8

[13] Oritz-Neu C, LeRoy C. The coincidence of Klinefelter's syndrome and systemic lupus erythematosus. Arthritis Rheum. 1969, 12: 241-246.

[14] Wittori, R, Desaegher L. Lupus érythémareux dissémine et porphyre aigu intermittente. Association or coincidence? Sem. Hop. Paris 1977, 53: 1542-1548,

[15] Folomeev M, Koshelev M, Alekberova Z. Systemic lupus erythematosus associated with Klinefelter's syndrome - a case report from the USSR. Rheumatol. 1991, 18: 140-141.

[16] Stern, R, Fishman J, Brushman H, Kunkel HG. Systemic lupus erythematosus associated with Klinefelter's syndrome, Arthritis Rheum. 1977, 20: 18-22.

[17] Lahita GR. The influence of sex hormones on the disease systemic lupus erythematosus. Springer Semitu Immunopathol 1986, 9: 305-314.

[18] Michalski JR, Snyder SM, McLeod RI, Talal N. Monozygotic twins with Klinefelter's syndrome discordant for systemic lupus erythematosus and symptomatic myasthenia gravis. Arthritis Rheum. 1978, 21: 306-309.

[19] Lahita GR, Bradlow H.L. Klinefelter's syndrome: hormone metabolism in hypogonadal males with systemic lupus erythematosus. J. Rheumatol, 1987, 14 (Suppl. 13): 154-157.

[20] French MAH, Hughes R. Systemic lupus erythematosus and Klinefelter's syndrome. Ann. Rheum. Dis. 1983, 4: 471—473,

[21] Gilliland WR, Stashower ME. Klinefelter's syndrome and systemic lupus erythematosus, Clin. Exp. Rheumatol, 2000, 18: 107-109.

[22] Jiménez-Balderas FF, Tapia-Serrano T, Fon-Seca T, et al. High frequency of association of rheumatic/autoimmune diseases and untreated male hypogonadism with severe testicular dysfunction. Arteritis Res. 2001, 3: 362-367.

[23] Dubois EK, Kaplan BJ. SLE and Klinefelter's syndrome. Lancet i: 1976. 93.

[24] Goto Y, Uhara H, Murata H, et al. Leg ulcers associated with positive lupus anticoagulant in two cases of Klinefelter's syndrome. Acta Dermato-venerologica, 2011, 91: 90-91
[25] Dillon S, Aggarwal R, Harding JW, et al. Klinefelter's syndrome (47XXY) among men with systemic lupus erythematosus. Acta Pediatr, 2011, Jun 100 (6): 819-23

[26] Scofield RH, Bruner GR, Nanijou B, et al. Klinefelter's syndrome $(47, X X Y)$ in male systemic lupus erythematosus patients; support for the notion of a gene - dose effect from the $\mathrm{X}$ chromosome. Arthritis Rheum. 2008, 58: 2511-2517

[27] Sawalha AH, Hartey JB, Scofield RH. Autoimmunity and Klinefelter's syndrome: when men have two X chromosomes. J Autoimm 2009, 33: 31-34

[28] Rovenský J, Kovalancik M, Payer J, Köhler K. Klinefelter's syndrome with antisynthetase syndrome. Clin. Rheumatol 2003, 9: 62-63.

[29] Nielsen SMJ, Rascher C, Temlett JA, Fritz VU. Polymyositis associated with Klinefelter's syndrome. SAMJ1999, 89: 420-421.

[30] Murakami, M Kishino B, Fushimi H, Sakata Y, Matsuyuki Y. The first report of Klinefelter's syndrome associated with polymyositis. Nippon Naika Cakkai Zashiu. 1988, 7: 530-535.

[31] Nowlin NS, Zwillich SH, Brick JE, Carlson HE. Male hypogonadism and scleroderma, Rheumatol. 1985, 12: 605-606.

[32] O'Donoghue DJ: Klinefelter's syndrome associated with systemic sclerosis. Postgrad Med. J.1982, 58: 575-576.

[33] De Keyser R, Mielantes H, Veys EM. Klinefelter's syndrome and scleroderma. J Rheumatol 1989, 16:1613-1614.

[34] Takeuchi IC, Murata Y, Sintani J et al. Klinefelter's syndrome accompanied by mixed connective tissue disease and diabetes mellitus. Int Med, 1999, 38, 875-881

[35] Kasten R, Phirrmann G, Voghtlander V. Klinefelter's syndrome associated with mixed connective disease and thrombophilia with postthrombotic syndrome. J Dtsch Dermatol Ges, 1995, 3: 623-626

[36] Ishihara $\mathrm{K}$, Yoshimura $\mathrm{M}$, Nakao $\mathrm{H}$ et al. T cell abnormalities in mixed connective tissue disease complicated Klinefelter's syndrome. Intern med, 1997, 33: 714-717

[37] Fujimoto M, Ikeda K, Nakamuri T, Iwamoto T, Furuta S, Nakajima H. Development of mixed connective tissue disease and Sjogren's syndrome in a patient with trisomy X. Lupus, 2015, 11: 1217-20

[38] Miyagawa S, Matsura E, Kitamura W et al. Systemic lupus erythematosus and anticardiolipin antibodies in Klinefelter's syndrome. Lupus, 1995, 4: 236-8

[39] Amstrong RD, McFarlaneDG, PanyiGS. Ankylosing spondylarthritis and Klinefelter's syndrome: does the $X$ chromosome modify disease expression? Br J Rheumatol, 1985, 24, $277-81$. 